\title{
TECHNICAL WRITING ASSIGNMENTS AND THE LAW
}

\author{
Christine Parkin
}

I decided to explore this topic when a colleague of mine asked me if there could be any legal implications arising from the type of assignments generally produced in our technical writing course, English 301, at U.B.C. My first reaction was that the formal links between the areas of law and technical writing assignments are tenuous, and on closer examination this still holds. None of our assignments for this course is a legal document as such: we do not ask our students to draft a writ of summons, a petition for divorce, or a contract. We are, after all, teachers of technical writing operating within the confines of the university or college environment. There seems to be, nevertheless, a perception that our assignments come closer to the business, and thus the legal, arena than do, say, essays on King Lear or criticisms of Shelley's poetry. This was highlighted yet again when another of my colleagues was wondering whether there could be any unpleasant repercussions from a Technical Writing report that one of his students was writing for English 301 based on material gleaned from a down town firm; the firm wanted a copy of the student report as part of its recompense for supplying the problem situation and information on which the report could be based and recommendations for improvement made. Broadly speaking, it is safe to say that the fact that the report was written primarily as an assignment for English 301 would protect the student and the instructor from any liability.

Statute law comes into play to protect the teacher in the institutional environment. In B.C. we have the University Act (R.S.B.C. 1979 Chap. 419), section 83 of which is headed, "No liability for acts of students." This section protects the employee of a university in broad terms in respect of acts or omissions of students. Section 84, in turn, protects the employee of a university from liability in respect of acts or omissions done or omitted in good faith in the course of the execution of his/her duties on behalf of the university.

This would seem to put an end to the matter and signal the end of this paper. As you will have guessed, however, there is more to say. I could see there was something fertile here which might grow into useful fruit for 
teachers of technical writing. In our technical writing course we deal with the writing of-among other things--business letters, memoranda, problemsolving reports, and job applications. Occasionally, we run across colleagues, and sometimes even students, who seem to think these tasks lack gravity. It can do no harm to point out that when our students write such things in the future, serious consequences could, in fact, attend upon them. A business letter could form part of a contract; a report could be relied upon with catastrophic results; a job application could misrepresent the facts; and anything we write could come into court as evidence. It adds a certain piquancy to the teaching of these assignments to pass this information on to our students; moreover, such knowledge encourages students to approach the assignments with more care and purpose.

When our students move into the work force, they are more likely to be writing 301-type assignments than critical essays. Indeed, it is almost breathtaking to contemplate just how many memoranda, letters and reports the average professional will write during a working year. It seems to me, therefore, that if we can encourage our students to view these assignments as a preparation for those they will later write during the working day, we will be doing them a service. With this in mind, I shall now move on to look at certain assignments individually.

\section{The Business Letter}

It is possible that a business letter could form part of a contract. The letter could be an offer; its reply could be an acceptance. The two together then constitute a promise in exchange for a promise and we have a bilateral contract.

A business letter might come into court to be used as evidence. In this case it is used as evidence of the contents of that letter. In comparison, if there is a bullet hole in the wall, this could be used as evidence that someone shot a gun in that room. A letter, however, except in the rarest circumstances, is used as evidence of the contents therein.

If you sign a letter, the strong assumption is that you are prepared to be accountable for the contents of that letter. If you have a letter from the Honda dealer saying, "This car has a V-8 engine," then that is held to be a true representation.

Students often want to know what the implications are if the secretary signs a letter on behalf of the boss. If this is the usual practice, then it is 
equal to a representation that he/she is authorized to sign. He/she (the secretary) is holding out this representation. Similarly, the company, by allowing the secretary to sign a letter on their headed paper, is implying that such a person has the authority to sign.

Needless to say, professionals have to be very careful about this procedure. The wise will allow the secretary to sign for them only for minor matters. If you sign on behalf of the boss, the strong suggestion is that you are acting as his/her agent. This gets us into the complex area of the law of agency. Briefly stated, an agent can have complete or limited authority. In the case of limited authority you might say to someone, "While I'm away, you can sell my car." This is an agency of specific purpose which is set out in the agency agreement. In the case of complete authority you would say, "He is my agent." The problem arises when an agent purports to have unlimited authority when he, in fact, has limited authority. If he then signs a document, his principal may be bound because a third party, who is innocent, relies on this.

A scenario my son likes to run by me is a variant on a case called Gibbs v. Messer. In my son's version, the parents go on holiday leaving an agreement that the son can sign cheques for them to Hydro, B.C. Telephone Co. etc. The son then sells their house! The parents', who are the principals, trouble is that if they've held out the agent as having full authority then they could be bound by this. What is the moral of this story? If a principal sets up an agent, then he/she must be very careful to delineate the limits of that agent's authority. To give a simple example: most firms have a printed letterhead which lists the names of the partners. The company should strike a retired member's name from that letterhead. Simple precautions should be taken. If you appoint an agent, state clearly in the agency agreement what the limits are. If you are a third party dealing with an agent (and you know this), ask to see the agency agreement and see what the agent is empowered to do.

So, back to our letter signed by the secretary. If the secretary signs per principal, then the principal stands behind that. Let's imagine that a secretary sends out letters from the office on the firm's headed paper without the authority to do so. The aggrieved party then sues. Who gets sued? The secretary, the principal, the firm; in short, everyone in sight. So, as the principal you will get sued, but you will "third party" the culprit, claiming fraud. I have found that if some of this information is passed on to students, it can make the writing of business correspondence a more challenging task. More care is taken with content, format, and layout. 


\section{The Maior Report}

In devising our 301 formal report, we make every effort to make the situation as realistic as possible. We therefore encourage the student to find a problem in the actual business world as the basis for the report. For example, I once had a student who wrote her report on which word processor a certain law firm should buy. She found out what the needs of the firm were; she gathered information on a variety of makes and models; and she wrote a set of recommendations which laid out very fully what the firm's options were and which machine she would advise them to buy. We had every reason to believe that the firm would act on her report.

Is it possible that the student who wrote this report could be sued and held liable for negligent or fraudulent misrepresentation? The test in such a case would be as follows: the injured party has relied on the representation, and that reliance is reasonable, and the relying party has suffered damage. The big test case in this area (Hedley Byme v. Heller) arose in the context of relying on a banker's report that a certain company was a good financial risk. The case has been applied in many circumstances including, for example, a real estate appraisal, and a medical opinion given for life insurance purposes.

Does the advice have to be paid for in order to fall under the test? No. If, however, money changes hands then this would go to the question of whether or not the reliance was reasonable: "I paid $\$ 500$ for this too!"

So looking at the test, which stresses that the reliance on the representation must be reasonable, our 301 report is very probably totally in the clear. The writer is a student and the report is being written as an assignment for a course. But there can be no harm in letting the student put in a disclaimer: "The writer accepts no liability in the event that someone relies on this report." The title page of the report should also state clearly that the report is an assignment for English 301 (or whatever the relevant course is named and numbered). Following my own precept, let me state here that this paper is not intended to be viewed as in any way providing legal advice!

\section{The Job Application}

The job advertisement and subsequent application by the candidate become part of the contract of hiring. This brings us into the area of contract law and of employment law (formerly termed Master and Servant). 
So, let's have a look at the student who is composing a c.v. or a resume. It is an implied term of any employment contract that any representations made by both sides are correct. It is very unwise to put lies in a resume; however, some students admit to "fudging" a few items.

If the job advertisement has stated that the candidate must have an M.A. in English, then this would prove to be a condition of the contract. If a condition is breached it goes to the root of the contract and the contract is at an end. A warranty in the contract is a term which is not essential. For example, if your contract says that the candidate shall commence work on September 5th and you turn up a day late, you could be docked a day's pay. The contract, however, is intact. So by falsifying certain items on a resume you may be in breach of contract.

Under the separate head of tort, you might also be sued for giving false information on a job application. You could be held liable for negligent or fraudulent misrepresentation. If there is fraudulent misrepresentation then the injured party is entitled to an action for damages for deceit; such damages are not designed to reimburse him for his loss, but are awarded as a punishment for fraud. In the case of misrepresentation in some jobs, statute comes into play. For example, the practice of medicine is governed by statute. It is an offence to practice if you are not qualified. The students should be advised to be as accurate as possible when composing a résume. Certain items, such as "I am fond of reading," would be seen as innocent puffery if it was found that the candidate didn't do much reading! "I have a degree in English," however, would be taken as a declaration of fact.

\section{Anything We Write Could be Used as Evidence}

Any document relevant to litigation has to be disclosed. Its existence must be made known to your lawyer. Each side then prepares an itemized list. Your lawyer then divides the documents into privileged and nonprivileged documents. The latter are then photo-copied and sent to the other side. An example of a privileged document would be anything passing between client and lawyer in contemplation of litigation. When the opposing lawyer sees a list of privileged documents he can challenge one, saying it is not privileged. The judge will then decide the matter.

Since, therefore, anything we write may unexpectedly become evidence, it behooves us to make sure that memos, letters, reports, and job applications have internal consistency so that, at the very least, we don't 
look incompetent or foolish if they arrive in court, and, of course, at the other extreme, we don't turn out to have been dishonest. Unlikely though it is that student assignments will finish up in court, it may not be a bad idea to remind our students that their future business writing could do so. Our training should encourage them to think carefully before they put pen to paper. Acknowledging some of the possible legal implications of their work is very useful in that respect.

Christine Parkin is a member of the Department of English, University of British Columbia. 